\title{
PERAN PEMBIAYAAN ARRUM PEGADAIAN SYARIAH TERHADAP PENGEMBANGAN USAHA MIKRO DI BANJARMASIN
}

\author{
Dewi Indah Astuti ${ }^{1}$ \\ Mochammad Arif Budiman ${ }^{2}$ \\ 1,2 Prodi Akuntansi Lembaga Keuangan Syariah, Politeknik Negeri Banjarmasin \\ Email: d030416005@akuntansipoliban.ac.id, m.arif.budiman@poliban.ac.id
}

\begin{abstract}
Arrum is a loan scheme from Sharia Pawnshops aimed at micro-businesses in the community. The purpose of this study is to determine the role of Arrum financing in the Sultan Adam Banjarmasin Sharia Pawnshop Unit in the development of micro-businesses. The type of this research is field research using a qualitative approach, while the data is obtained by observation and interview methods. The results show that Arrum financing contributed to the development of micro-businesses by increasing business capital, number of customers, and operating income. The implication of this research is that the Sultan Adam Banjarmasin Sharia Pawnshop Unit needs to continue to expand Arrum's financing products, improve promotion and service quality.
\end{abstract}

Keywords: Arrum Financing, Business Development, Rahn, Micro Business

\section{PENDAHULUAN}

Pegadaian merupakan salah satu lembaga keuangan non-bank di Indonesia yang berfungsi menyalurkan pembiayaan melalui pinjaman uang berdasarkan prinsip gadai kepada masyarakat yang membutuhkan (Kasmir, 2012). Pegadaian menyediakan pembiayaan dengan prinsip fidusia/pengalihan hak kepemilikan sebuah benda sebagai jaminan atas pinjaman yang diberikan namun hak kepemilikannya masih berada pada pemilik benda tersebut, sedangkan pola pembayarannya dilakukan secara angsuran.

Seiring dengan munculnya kesadaran masyarakat untuk bertransaksi secara syariah, kemudian lahirlah pegadaiaan syariah yang menjalankan operasionalnya dengan mengacu pada prinsip-prinsip syariah sebagaimana diatur dalam Fatwa DSN-MUI No. 25/DSN-MUI/III/2002 tentang Rahn. Dalam fiqh Islam, gadai disebut rahn, yaitu menggadaikan sejumlah harta yang diserahkan sebagai jaminan, tetapi dapat diambil kembali sebagai tebusan.

Salah satu produk pegadaian syariah adalah produk Arrum yang ditujukan untuk mengatasi persoalan keterbatasan modal yang dihadapi oleh kelompok usaha mikro. Keterbatasan modal merupakan salah satu problem utama bagi para pelaku UMKM mengingat mereka pada umumnya tidak mampu memenuhi persyaratan pengajuan kredit/pembiayaan di bank (non-bankable) (Hartono \& Hartomo, 2016). Akibatnya, tidak jarang pelaku UMKM terpaksa melakukan pinjaman modal kepada rentenir karena prosesnya yang mudah, meskipun dengan biaya bunga yang tinggi (Siboro, 2015). Hal ini dapat menjadi beban dan berakibat buruk bagi kelangsungan usaha mereka.

Arrum merupakan skim peminjaman yang menggabungkan dua akad, yaitu akad rahn dan akad ijarah. Dalam akad rahn nasabah menyerahkan barang bergerak dan kemudian pegadaian menyimpan dan merawatnya di tempat yang telah disediakan oleh pegadaian. Akibat yang muncul dari proses penyimpanan adalah timbulnya biaya-biaya yang meliputi biaya investasi tempat penyimpanan, biaya perawatan, dan biaya operasional transaksi (Muftifiandi, 2015). Sedangkan ijarah adalah akad pemindahan hak guna atas barang dan atau jasa melalui pembayaran upah atau sewa tanpa diikuti dengan pemindahan kepemilikan atas barangnya (Lisara, 2017).

Produk Arrum menawarkan kemudahan akses bagi pelaku usaha mikro untuk memperoleh pembiayaan hanya dengan jaminan BPKB (Bukti Pemilikan Kendaraan Bermotor), dimana kendaraan tetap berada pada pemiliknya sehingga bisa tetap digunakan untuk mendukung aktivitas usahanya sehari-hari. Apabila jaminan telah dinyatakan sesuai peraturan yang ditetapkan pegadaian, proses 
penyaluran dana hanya membutuhkan waktu tiga hari dan pelunasan dapat dilakukan sewaktu-waktu (Mutmainna, 2012).

Ada beberapa penelitian tentang Arrum di antaranya adalah riset dari Arfah (2019) dimana riset ini menghasilkan kesimpulan bahwa Pembiayaan produk Arrum oleh Pengadaian syariah cabang Pandau Permai memberikan manfaat dapat mengembangkan ekonomi bagi usaha mikro dan kecil, hal ini ditandai dengan meningkatnya usaha yang dijalankan mereka. Penelitian lainnya dilakukan oleh Novriansyah dan Sri (2019) yang dilakukan pada Pegadaian Surabaya hasilnya adalah produk Arrum mampu meningkatkan standar usaha pelaku usaha mikro dan kecil berupa meningkatnya standar kemampuan manajemen, pemasaran dan omset.

Secara empiris dua penelitan tadi memberikan gambaran bahwa produk pembiayaan Arrum dapat membantu pengembangan usaha mikro dalam aspek permodalan. Namun sejauh ini belum ada proses evaluasi terkait peran produk Arrum terhadap pengembangan usaha mikro yang ada di Cabang Banjarmasin, khususnya yang disalurkan oleh Pegadaian Syariah Unit Sultan Adam Banjarmasin. Berdasarkan hal tersebut, penulis terdorong untuk melakukan penelitian ini yang secara khusus bertujuan untuk menganalisis peran pembiayaan Arrum terhadap pengembangan usaha mikro di Pegadaiaan Syariah Unit Sultan Adam Banjarmasin.

\section{TINJAUAN LITERATUR}

\section{Pegadaian Syariah}

Pegadaian dalam bahasa Arab disebut ar-rahn yang berarti menyimpan sementara harta milik si peminjam sebagai jaminan peminjaman yang diberikan oleh orang yang meminjamkan (yang berpiutang). Dalam istilah perbankan, barang objek gadai ini dikenal sebagai jaminan (kolateral) (Lisara, 2017).

Rukun gadai meliputi: ar-rahin (pihak yang menggadaikan), al-murtahin (pihak yang menerima gadai), al-marhun (barang yang digadaikan), al-marhun bih (utang), dan sighat (pernyataan ijab dan qabul). Pada dasarnya pegadaian syariah mengandung dua akad, yaitu (1) akad rahn, dimana pegadaian menahan barang sebagai jaminan atas utang nasabah, dan (2) akad ijarah, yaitu akad pemindahan hak guna atas barang atau jasa tanpa diikuti dengan pemindahan kepemilikan atas barangnya. Melalui akad ini, pegadaian menarik sewa atas penyimpanan barang nasabah yang telah melakukan akad.

Dalam menjalankan operasinya Gadai Syariah berlandaskan Fatwa Dewan Syariah Nasional nomor: 25/DSN-MUI/III/2002 tanggal 26 Juni 2002 tentang rahn, fatwa nomor: 26/DSNMUI/III/2002 tentang rahn emas dan : 68/DSN-MUI/III/2008 tentang rahn tasjily

. Dalam fatwa DSN menyatakan bahwa pinjaman dengan menggadaikan barang sebagai jaminan utang dalam bentuk rahn diperbolehkan dengan ketentuan sebagai berikut :

a) Murtahin (penerima barang) mempunyai hak untuk menahan Marhun (barang) sampai semua utang rahin (yang menyerahkan barang) dilunasi.

b) Marhun dan manfaatnya tetap menjadi milik rahin. Pada prinsipnya marhun tidak boleh dimanfaatkan oleh murtahin kecuali seizin rahin, dengan tidak mengurangi nilai marhun dan pemanfaatannya itu sekadar pengganti biaya pemeliharaan perawatannya.

c) Pemeliharaan dan penyimpanan marhun pada dasarnya menjadi kewajiban rahin, namun dapat dilakukan juga oleh murtahin, sedangkan biaya dan pemeliharaan penyimpanan tetap menjadi kewajiban rahin.

d) Besar biaya administrasi dan penyimpanan marhun tidak boleh ditentukan berdasarkan jumlah pinjaman.

e) Penjualan marhun

1) Apabila jatuh tempo, murtahin harus memperingatkan rahin untuk segera melunasi utangnya.

2) Apabila rahin tetap tidak melunasi utangnya, maka marhun dijual paksa/dieksekusi.

3) Hasil Penjualan marhun digunakan untuk melunasi utang, biaya pemeliharaan dan penyimpanan yang belum dibayar serta biaya penjualan.

4) Kelebihan hasil penjualan menjadi milik rahin dan kekurangannya menjadi kewajiban rahin. Dari landasan syariah yang telah dibahas pada bagian sebelumnya, adapun mekanisme operasional Pegadaian Syariah dapat digambarkan sebagai berikut: melalui akad rahn, 
nasabah menyerahkan barang bergerak dan kemudian Pegadaian menyimpan dan merawatnya di tempat yang telah disediakan oleh Pegadaian. Akibat yang timbul dari proses penyimpanan adalah timbulnya biaya-biaya yang meliputi nilai investasi tempat penyimpanan, biaya perawatan dan keseluruhan proses kegiatannya

\section{Produk Arrum}

Arrum (Ar-Rahn untuk Usaha Mikro) di Pegadaian Syariah merupakan produk dimana nasabah yang mempunyai usaha mikro dapat mengajukan pembiayaan untuk menambah modal usaha dengan jaminan surat kendaraan, yaitu BPKB atau barang berharga lainnya. Mekanisme penyaluran dan pembiayaan, yang pertama, pihak Pegadaian menerima berkas pengajuan pembiayaan Arrum dari nasabah. Kedua, memeriksa keabsahan dokumen-dokumen yang dilampirkan oleh nasabah dan melakuakan survei analisis kelayakan usaha serta menaksir agunan. Ketiga, pencairan dana pembiayaan Arrum setelah menandatangani akad pembiayaan.

Landasan hukum produk Arrum adalah Fatwa DSN No. 68/DSN-MUI/III/2008 tentang Rahn Tasjily yaitu jaminan dalam bentuk barang atau uang dengan kesepakatan bahwa yang diserahkan kepada penerima jaminan hanya bukti sah kepemilikannya. sedangkan fisik barang jaminan tersebut (marhun) tetap berada dalam penguasaan dan pemanfaatan pemberi jaminan (rahin). Beberapa ketentuan terkait rahn tasjily adalah sebagai berikut:

1. Biaya pemeliharaan harus ditanggung oleh pihak yang menggadaikan, namun jumlah biaya pemeliharaan tidak boleh dihubungkan dengan besarnya pembiayaan.

2. Pihak penerima gadai dapat menyimpan bukti kepemilikan, sedangkan barang yang digadaikan dapat digunakan pihak yang menggadaikan dengan izin dari pihak penerima gadai.

3. Jika terjadi penunggakan maka jaminan dapat dijual oleh pihak penerima gadai tetapi harus dengan izin dari pihak yang menggadaikan sebagai pemilik.

Menurut Arfah (2019) akad yang diterapkan dalam barang jaminan nasabah yang menggunakan pembiayaan produk Arrum adalah akad jaminan fidusia. Yang mana jaminan fidusia ini yang dijadikan jaminan pembiayaan adalah surat bukti kepemilikan barang atas nama milik sendiri dan tidak dalam penguasaan orang lain atau tidak sebagi objek sengketa. Sedangkan marhum diserahkan kenbali kepada nasabah untuk menyimpan dan merawatnya, jika terjadi kerusakan dan kehilangan maka nasabah menanggung resikonya. tapi marhum yang dipegang oleh nasabah boleh dimanfaatkan dan digunakan karena mendapat izin dari masing-masing pihak bersangkutan. Dalam Islam tentang pemanfaatkan dan pengunaan barang gadai dibolehkan, jika mendapat izin diatara kedua belah pihak.

\section{UMKM (Usaha Mikro Kecil Menengah)}

UMKM adalah usaha milik perorangan yang bukan di bawah perusahaan besar yang mampu memberikan lapangan pekerjaan sehingga meningkatkan pendapatan masyarakat dan berimbas pada pembangunan ekonomi. Di Indonesia definisi UMKM diatur berdasarkan Undang-Undang Republik Indonesia Nomor 20 Tahun 2008 tentang Usaha Mikro, Kecil dan Menengah sebagai berikut:

1. Usaha Mikro, yaitu usaha produktif milik orang perorangan atau badan usaha perorangan yang memenuhi kriteria usaha mikro, yaitu memiliki kekayaan bersih paling banyak Rp 50.000.000,00 (lima puluh juta rupiah) tidak termasuk tanah dan bangunan tempat usaha; atau memiliki hasil penjualan tahunan paling banyak Rp 300.000.000,00 (tiga ratus juta rupiah).

2. Usaha Kecil, yaitu usaha ekonomi produktif yang berdiri sendiri, yang dilakukan oleh orang perorangan atau badan usaha yang bukan merupakan anak perusahaan atau bukan cabang perusahaan yang dimiliki, dikuasai, atau menjadi bagian baik langsung maupun tidak langsung dari usaha menengah atau usaha besar yang memenuhi kriteria usaha kecil, yaitu memiliki kekayaan bersih lebih dari Rp 50.000.000,00 (lima puluh juta rupiah) sampai dengan paling banyak Rp 500.000.000,00 (lima ratus juta rupiah) tidak termasuk tanah dan bangunan tempat usaha; atau memiliki hasil penjualan tahunan lebih dari Rp 300.000.000,00 (tiga ratus juta rupiah) sampai dengan paling banyak Rp 2.500.000.000,00 (dua milyar lima ratus juta rupiah).

3. Usaha Menengah, yaitu usaha ekonomi produktif yang berdiri sendiri, yang dilakukan oleh orang perorangan atau badan usaha yang bukan merupakan anak perusahaan atau cabang perusahaan yang dimiliki, dikuasai, atau menjadi bagian baik langsung maupun tidak langsung dengan usaha kecil atau usaha besar dengan jumlah kekayaan bersih atau hasil penjualan tahunan dengan kriteria memiliki kekayaan bersih lebih dari Rp 500.000.000,00 (lima ratus juta rupiah) sampai dengan 
paling banyak Rp 10.000.000.000,00 (sepuluh milyar rupiah) tidak termasuk tanah dan bangunan tempat usaha; atau memiliki hasil penjualan tahunan lebih dari Rp 2.500.000.000,00 (dua milyar lima ratus juta rupiah) sampai dengan paling banyak Rp 50.000.000.000,00 (lima puluh milyar rupiah).

UMKM pada umumnya memiliki karakteristik sebagai berikut;

1. Usaha Mikro: (a) jenis barang/komoditi tidak tetap sewaktu-waktu dapat berganti; (b) tempat usahanya tidak selalu menetap sewaktu-waktu dapat berpindah; (c) belum melakukan administrasi keuangan yang sederhana sekalipun; (d) tidak memisahkan keuangan pribadi dengan keuangan usaha; dan (e) tingkat pendidikan rata-rata sangat rendah. Contohnya pedagang kaki lima, pedagang di pasar.

2. Usaha Kecil: (a) jenis barang/komoditi umumnya sudah tetap tidak gampang berubah; (b) tempat usahanya umumnya sudah menetap tidak berpindah-pindah; (c) sudah melakukan administrasi keuangan walaupun masih sederhana; (d) sudah mulai ada pemisahan antara keuangan pribadi dan keuangan usaha; dan (e) sudah membuat neraca usaha. Contohnya pedagang di pasar grosir/agen dan pedagang pengumpul lainnya.

3. Usaha Menengah: (a) memiliki manajemen dan organisasi yang lebih baik dengan pembagian tugas yang jelas antara bagian keuangan dan bagian pemasaran dan bagian produksi; (b) telah melakukan manajemen keuangan dengan menerapkan sistem akuntansi dengan teratur; (c) telah melakukan aturan atau pengelolaan dan organisasi perburuhan; (d) sudah memiliki akses kepada sumber-sumber pendanaan perbankan maupun LKNB; dan (e) pada umumnya telah memiliki SDM yang terlatih. Contohnya usaha pertambangan batu untuk konstruksi dan marmer buatan (Nabila, 2019).

\section{Pengembangan dan Tantangan UMKM}

Kegiatan ekonomi berskala mikro, kecil dan menengah merupakan penggerak perekonomian daerah, sedangkan perekonomian daerah merupakan penopang pertumbuhan ekonomi nasional. UMKM merupakan sektor usaha yang tergolong tangguh di tengah krisis ekonomi. Penelitian Hasri et al. (2014) menunjukkan bahwa pengembangan UMKM terbukti mampu menjadi faktor pendorong pertumbuhan ekonomi daerah serta membawa dampak positif terhadap penyerapan tenaga kerja dalam upaya pengentasan kemiskinan.

Meskipun demikian, UMKM masih menghadapi banyak tantangan atau persoalan dalam pengembangan usahanya. Di antara tantangan tersebut adalah pengelolaan organisasi yang kurang efektif terutama aspek sumber daya manusia, kepemimpinan yang tidak efektif, kurangnya komitmen anggota untuk memajukan kelompok usahanya, administrasi kelompok yang tidak rapi, kurangnya kemauan untuk berinovasi, dan rasa cepat puas terhadap hasil kerja (Naufalin, 2020). Selain itu, persoalan yang juga seringkali muncul dalam pengembangan UMKM di Indonesia adalah terkait dengan pembiayaan, pembangunan infrastruktur usaha, sarana fisik dan kolaborasi dengan seluruh stakeholder, termasuk kualitas sumber daya manusia (Zaelani, 2019).

Menurut Suci (2017) UMKM di Indonesia telah menjadi bagian penting dari sistem perekonomian di Indonesia. Hal ini dikarenakan UMKM merupakan unit-unit usaha yang lebih banyak jumlahnya dibandingkan usaha industri berskala besar dan memiliki keunggulan dalam menyerap tenaga kerja lebih banyak dan juga mampu mempercepat proses pemerataan sebagai bagian dari pembangunan.

\section{METODE PENELITIAN}

Penelitian ini merupakan penelitian kualitatif dengan memanfaatkan sumber data primer dan data sekunder. Data primer berasal dari observasi langsung di lapangan dan wawancara, baik dengan pegawai Pegadaiaan Syariah Unit Sultan Adam Banjarmasin maupun dengan nasabah Arrum, sedangkan data sekunder berasal dari dokumen dan literatur yang terkait dengan topik penelitian. Adapun teknik analisis data yang digunakan adalah analisis deskriptif-analitik, yaitu menjelaskan data yang diperoleh, melakukan klasifikasi dan analisis, kemudian menyimpulkan hasilnya. 


\section{Gambaran Perusahaan dan Profil Responden}

\section{HASIL PENELITIAN DAN PEMBAHASAN}

Pegadaian Syariah didirikan di Jakarta pada tanggal 14 Januari 2003 yang dimaksudkan untuk memenuhi keinginan nasabah untuk bertransaksi dengan akad syariah. Pendirian Pegadaian Syariah didorong oleh perkembangan dan keberhasilan lembaga-lembaga keuangan syariah lainnya, dan juga didasari oleh kebutuhan masyarakat Indonesia terhadap hadirnya sebuah pegadaian yang menerapkan prinsip-prinsip syariah. Sedangkan Pegadaian Syariah Unit Sultan Adam yang beroperasi di kota Banjarmasin didirikan pada tanggal 1 April 2009. Selama sebelas tahun beroperasinya, kantor unit ini telah mengalami perkembangan positif dari sisi kinerja usaha dan jumlah nasabahnya. Adapun produk dan jasa yang disediakan meliputi Rahn (gadai syariah), Arrum (Rahn untuk Usaha Mikro), Arrum Haji (dana talangan haji), dan Amanah.

Responden utama dari penelitian ini adalah para nasabah yang mengajukan dan mendapatkan pembiayaan Arrum dari Pegadaian Syariah Unit Sultan Adam. Peneliti mewawancarai sebanyak lima orang responden yang bersedia menyediakan waktunya untuk diwawancarai dengan profil sebagaimana dalam Tabel 1.

Tabel 4.1

\section{Profil Responden}

\begin{tabular}{|l|l|c|}
\hline \multicolumn{2}{|l|}{ Variabel } & Jumlah \\
\hline \multirow{3}{*}{ Jenis Kelamin } & Laki-laki & 3 orang \\
\cline { 2 - 3 } & Perempuan & 2 orang \\
\hline \multirow{3}{*}{ Pendidikan Terakhir } & SLTA & 4 orang \\
\cline { 2 - 3 } & S1 & 1 orang \\
\cline { 2 - 3 } & Pengusaha kayu & 1 orang \\
\cline { 2 - 3 } & Bengkel motor & 1 orang \\
\cline { 2 - 3 } & Fotocopy & 1 orang \\
\cline { 2 - 3 } & Toko sembako & 1 orang \\
\cline { 2 - 3 } & Laundry & 1 orang \\
\hline \multirow{3}{*}{ Lama Usaha } & 1 tahun & 2 orang \\
\cline { 2 - 3 } & 2 tahun & 4 orang \\
\hline \multirow{2}{*}{ Sumber Informasi } & Keluarga/kerabat & 1 orang \\
\cline { 2 - 3 } & Banner promosi &
\end{tabular}

Responden penelitian ini terdiri dari $60 \%$ laki-laki dan $40 \%$ perempuan. Dari aspek pendidikan, $80 \%$ responden mengenyam pendidikan SLTA, sedangkan sisanya berpendidikan S1. Jenis usaha yang digeluti responden bervariasi, yaitu pengusaha kayu, bengkel motor, fotocopy, toko sembako, dan laundry. Kegiatan usaha yang dijalankan responden umumnya masih relatif baru, yaitu antara 1-2 tahun sehingga dapat dikatakan masih dalam tahap perintisan dan pengembangan awal. Adapun sumber informasi terkait pembiayaan Arrum kebanyakan diperoleh responden dari keluarga atau kerabatnya (80\%), sedangkan yang memperoleh informasi melalui banner promosi yang dilakukan pihak pegadaian hanya 1 responden $(20 \%)$ saja. Ini menunjukkan bahwa peran dari keluarga atau kerabat lebih besar dan efektif dalam menginformasikan produk Arrum kepada para nasabah dibandingkan peran promosi yang dilakukan oleh pegadaian sendiri.

\section{Peran Pembiayaan Arrum dalam Pengembangan Usaha Mikro}

Pembiayaan Arrum hanya diperuntukkan bagi nasabah yang mempunyai usaha dan untuk memperoleh pembiayaan Arrum di Pegadaian nasabah cukup memberikan jaminan BPKB kendaraan. Jumlah pembiayaan nasabah berkisar antara Rp 3-15 juta dengan angsuran perbulan Rp 200-500 ribu dan jangka waktu angsuran selama 12-24 bulan.

Berdasarkan wawancara dengan para nasabah, pembiayaan Arrum dinilai berperan sangat positif dalam pengembangan usaha mereka. Nasabah pertama menyatakan bahwa pembiayaan Arrum digunakan untuk menambah stok kayunya sehingga dapat meningkatkan pendapatan usahanya. Stok kayu tersebut digunakan sebagai bahan pembuatan mebel, kursi, bahan bangunan rumah kayu, dan 
masih banyak lainnya. Nasabah kedua juga menyampaikan bahwa setelah mendapatkan pembiayaan Arrum persediaan barang bengkel dan pendapatannya meningkat, bahkan berencana menambahkan karyawan jika pendapatan bengkel bisa meningkat terus ke depannya. Menurut nasabah ketiga, pembiayaan Arrum sangat bagus dan berpengaruh terhadap peningkatan pendapatan usaha, kendati tidak terlalu besar. Nasabah ini berniat akan melanjutkan produk Arrum sampai batas pendapatan yang ditargetkan.

Nasabah keempat yang sudah menjadi nasabah selama dua tahun mengajukan pembiayaan Arrum untuk menambah persediaan bahan sembako dan merenovasi toko. Setelah itu, nasabah mengalami peningkatan omset penjualan, tidak pernah memiliki kendala dalam membayar angsuran, dan berencana akan melanjutkan produk tersebut. Sedangkan nasabah kelima pertama kali mengajukan pembiayaan sebesar Rp 10 juta dengan tujuan membeli mesin laundry yang baru. Dalam waktu setengah bulan berikutnya pelanggannya makin banyak berdatangan sehingga omsetnya pun meningkat.

Tabel 4.2

Kenaikan pendapatan nasabah

\begin{tabular}{|c|c|c|c|c|c|}
\hline \multirow[b]{2}{*}{ Responden } & \multirow[b]{2}{*}{ Jenis Usaha } & \multirow{2}{*}{$\begin{array}{l}\text { Modal Awal } \\
\text { (Rp) }\end{array}$} & \multicolumn{3}{|c|}{ Pendapatan } \\
\hline & & & Sebelum(Rp) & Sesudah (Rp) & $\begin{array}{c}\% \\
\text { Kenaikan }\end{array}$ \\
\hline 1 & Pengusaha kayu & 5.000 .000 & 2.000 .000 & 2.500 .000 & $25 \%$ \\
\hline 2 & Bengkel motor & 15.000 .000 & 4.000 .000 & 6.000 .000 & $50 \%$ \\
\hline 3 & Fotocopy & 5.000 .000 & 2.000 .000 & 2.500 .000 & $25 \%$ \\
\hline 4 & Toko sembako & 3.000 .000 & 1.000 .000 & 1.300 .000 & $30 \%$ \\
\hline 5 & Laundry & 10.000 .000 & 1.000 .000 & 3.000 .000 & $200 \%$ \\
\hline
\end{tabular}

Tabel di atas menunjukan bahwa modal awal nasabah berkisar antara Rp 3-15 juta, sedangkan kenaikan pendapatannya berkisar antara $25-200 \%$. Semua nasabah yang mendapatkan pembiayaan Arrum tercatat mengalami peningkatan pendapatan atau keuntungannya.

Hasil wawancara menunjukan bahwa pembiayaan Arrum pada Pegadaian Syariah dapat membantu nasabah dalam peningkatan usaha. Hal ini dapat dilihat pada respon nasabah yang memberikan pernyataan sangat setuju dan setuju jika pembiayaan Arrum dapat meningkatkan usaha nasabah. Hal ini disebabkan karena dana yang disalurkan kepada nasabah benar-benar dimanfaatkan dan tidak lepas dari manajeman keuangan yang baik dalam menjalankan usaha. Selain itu, nasabah yang mendapatkan pembiayaan ini sudah mempunyai pengalaman terhadap dunia usaha serta mampu membaca peluang tempat membuka usaha. Nasabah umumnya juga merasa sangat puas karena prosedur yang dianggap mudah, cepat, dan aman di samping pelayanan stafnya yang baik. Produk pembiayaan Arrum yang menggunakan BPKB kendaraan bermotor sebagai jaminan dipandang sangat memudahkan karena kendaraan masih tetap bisa digunakan untuk keperluan usaha.

Dari uraian para responden di atas tampak bahwa tambahan modal yang bersumber dari pembiayaan Arrum telah berkontribusi pada pengembangan usaha mikro dalam bentuk peningkatan kapasitas usaha berupa mesin, alat produksi, ataupun persediaan barang yang selanjutnya mendorong bertambahnya jumlah pelanggan. Jumlah pelanggan yang bertambah kemudian meningkatkan nilai penjualan dan akhirnya memperbesar nilai pendapatan/keuntungan. Kenaikan pendapatan usaha nasabah selanjutnya memberikan dampak positif pada kemampuan pembayaran angsuran secara tepat waktu oleh nasabah kepada Pegadaian Syariah serta berdampak pula pada keberlangsungan usaha yang dijalankan nasabah. Rata-rata nasabah juga tidak memiliki kendala dalam membayar angsuran untuk tahun-tahun yang sudah dijalani. Sebagian di antaranya bahkan berencana akan mengajukan pembiayaan Arrum yang baru meskipun tetap akan melihat perkembangan usahanya terlebih dahulu.

\section{KESIMPULAN}

Berdasarkan pembahasan dalam penelitian ini maka dapat ditarik kesimpulan bahwa pembiayaan Arrum yang disalurkan oleh Pegadaian Syariah terbukti dapat membantu nasabah dalam meningkatkan usahanya. Hal ini dapat dilihat dari terjadinya peningkatan jumlah pelanggan, nilai 
penjualan dan nilai pendapatan/keuntungan nasabah. Artinya, pembiayaan Arrum berperan positif terhadap pengembangan usaha mikro yang dikelola masyarakat. Dengan demikian, semakin tinggi pembiayaan Arrum yang disalurkan ke nasabah, maka akan semakin besar pula peran Pegadaian Syariah dalam perkembangan usaha mikro nasabah.

Peneliti menyarankan agar ke depannya Pegadaian Syariah dapat meningkatkan upaya sosialisasi dan promosi terhadap produk-produk yang ditawarkannya, khususnya produk Arrum, sehingga dapat meningkatkan jumlah nasabahnya. Pihak perusahaan juga perlu mempertahankan keramahan dalam pelayanan agar nasabah merasa nyaman atas pelayanan yang diberikan. Di samping itu, Pegadaian diharapkan melakukan pendampingan secara berkala dengan tujuan untuk memantau perkembangan usaha nasabah sekaligus menanggulangi agar dana pembiayaan Arrum tidak digunakan untuk kebutuhan konsumtif.

\section{DAFTAR PUSTAKA}

Arfah. (2019). Peranan Produk Ar-Rum dalam Pengembangan dalam Pengembangan usaha Mikro dan Kecil pada Pegadaian Syariah Cabang Pandau Permai Siak Hulu Kabupaten Kampar. Eko dan Bisnis (Riau Economics and Business Reviewe Volume 10, Nomor 1, Maret, 33-40

Fatwa DSN-MUI No. 25/DSN-MUI/III/2002 tentang Rahn.

Hartono, H., \& Hartomo, D. D. (2016). Faktor-Faktor yan g Mempengaruhi Perkembangan UMKM di Surakarta. Jurnal Bisnis Dan Manajemen, 14(1), 15. https://doi.org/10.20961/jbm.v14i1.2678

Hasri, B., Santoso, S., \& Santosa, D. (2014). Analisis Pengembangan USAha Mikro Kecil Menengah untuk Meningkatkan Pertumbuhan Ekonomi sebagai Upaya Pengentasan Kemiskinan dan Pengangguran Daerah di Kabupaten Ngawi. Jurnal Pendidikan Insan Mandiri.

Kasmir. (2012). Bank dan Lembaga Keuangan Lainnya. Jakarta: Raja Grafindo Persada.

Lisara, W. L. (2017). Pengaruh Modal dan Pembiayaan Arrum terhadap Perkembangan Usaha Studi pada Pegadaian Syariah Cabang Solo Baru, Surabaya. Institut Agama Islam Negeri Surakarta.

Muftifiandi. (2015). Peran Pembiayaan Produk Ar-Rum Bagi UMKM Pada PT Pegadaian (Persero) Cabang Syariah Simpang Patal Palembang. Universitas Islam Negeri Raden Fatah Palembang.

Mutmainna. (2012). Analisis Pembiayaan Arrum PT Pegadaian Syariah terhadap Pengembangan Usaha Mikro Kecil. Universitas Islam Negeri UIN Makassar.

Nabila, F. (2019). Klasifikasi UKM dan UMKM di Indonesia. Smartlegal.Id. https://smartlegal.id/smarticle/2019/02/13/klasifikasi-ukm-dan-umkm-di-indonesia/

Naufalin, L. R. (2020). Tantangan Pengembangan Usaha Mikro Kecil Menengah (UMKM) di Kabupaten Banyumas. 22(1), 95-102.

Novriansyah, Muh, Sri, Herianingrum. (2019). Peran Pembiayaan Produk Arrum BPKB PT Pegadaian Syariah dalam Mengembangkan Usaha Mikro Kecil dan Menengah di Kota Surabaya. Jurnal Ekonomi Syariah Teori dan Terapan Vol. 6 No. 8 Agustus: 1718-1732

Siboro, I. K. (2015). Rentenir (Analisis terhadap Fungsi Pinjaman Berbunga dalam Masyarakat Rokan Hilir Kecamatan Bagan Sinembah Desa Bagan Batu). Jom Fisip, 2, 1-15.

Subagiyo, Rokhmat. (2014). Tinjaun Syariah tentang Pegadaian. An-Nisbah, Vol. 01, No. 01, 162-183

Suci, Yuli Rahmini. (2017). Perkembangan UMKM di Indonesia. Jurnal Ilmiah Cano Ekonomos Vol. 6 No. 1 Januari, 51-58

Undang-Undang Republik Indonesia Nomor 20 Tahun 2008 tentang Usaha Mikro, Kecil dan Menengah.

Zaelani, I. R. (2019). Peningkatan Daya Saing UMKM Indonesia: Tantangan dan Peluang $\begin{array}{lllll}\text { Pengembangan Iptek. Jurnal Transborders, } & 3(1),\end{array}$ https://doi.org/ttp://dx.doi.org/10.23969/transborders.v3i1.1746 